\title{
KAJIAN ELEMEN PEMBENTUK IDENTITAS GENDER PADA RESTORAN BERTEMA PEREMPUAN DI KOTA BANDUNG
}

\author{
Aan Setiawati, Imam Santosa, Widiharjo \\ (Email: langitnyabiru27@gmail.com) \\ Jurusan Magister Desain \\ Fakultas Seni Rupa dan Desain \\ Institut Teknologi Bandung \\ Jl. Ganesha No. 10, Bandung, Indonesia
}

\begin{abstract}
ABSTRAK
Penelitian yang dilakukan merupakan kajian mengenai elemen identitas gender pada restoran bertema perempuan di kota Bandung. Studi kasus penelitian ini yaitu restoran Roemah Nenek dan Nanny's Pavillon. Penelitian ini bersifat kualitatif dengan melakukan pengujian berdasarkan teori yang mempersoalkan aspek-aspek penerapan identitas gender pada elemen interior restoran. Hasil dari penelitian yaitu konteks gender pada identitas restoran Roemah Nenek dan Nanny's Pavillon terbentuk dari brand serta sifat elemen interior yang memiliki korelasi dengan pemahaman stereotip masyarakat mengenai sifat perempuan, elemen-elemen interior restoran secara umum menunjukan konsistensi makna, yaitu konsep restoran memiliki makna yang setara dan saling medukung terhadap elemen interior yang menjadi identitas restoran, sehingga tidak adanya perbedaan korelasi makna, dan elemen interior terhadap persepsi pengamat pada restoran menampilkan konsistensi ekspresi yang sama antara sifat pada benda dan sifat yang muncul pada karakter perempuan serta apa yang dipersepsikan oleh pengamat.
\end{abstract}

Kata kunci : gender; identitas; interior; perempuan; tematik

\section{ABSTRACT}

This research is a study of gender identity element at female-themed restaurants in Bandung city. The case study of this research is restaurant Roemah Nenek and Nanny's Pavillon. This study is a qualitative test based on the theory that concern in the aspects of the implementation of gender identity in the restaurant interior elements. The result form this research is gender identity context at Restoran Roemah Nenek and Nanny's Pavillon is formed from the brand and the nature of the interior elements that have a correlation with the stereotypical understanding about the nature of female. Restaurant interior elements generally show consistency of meaning, that is the concept of the restaurant has a similar meaning and mutual support against the interior elements as identity of the restaurant. Thus, there is no difference in meaning and elements correlation to the perception of the observer about the restaurant. Perception observers show the same consistency of expression between the nature of objects and the nature that appear on female characters.

Keywords: female; gender; identity; interior; thematic 
Serat Rupa Journal of Design, January 2016, Vol.1, No.1: 50-63

Aan Setiawati - Elemen Pembentuk Identitas Gender pada Restoran Bertema Perempuan

di Kota Bandung

\section{PENDAHULUAN}

Penelitian yang dilakukan merupakan kajian mengenai elemen identitas gender pada restoran di kota Bandung. Identitas merupakan ciri khas yang membuat sesuatu berbeda dari yang lainnya, dapat diwujudkan melalui bentuk arsitektur, elemen estetik serta nilai yang dipahami dalam membentuk suatu lingkungan. Berhubungan dengan identitas, penelitian ini mengkaitkan persoalan mengenai kajian bidang arsitektur, khususnya interior dengan permasalahan gender yang menjadi identitas pada restoran tersebut.

Gender bukanlah jenis kelamin perempuan atau lelaki, melainkan merupakan sifat yang melekat pada laki-laki maupun perempuan yang dikonstruksi secara sosial maupun kultural. Seperti contoh sifat pada perempuan yaitu dikenal lemah lembut, cantik, emosional, atau keibuan. Sedangkan pada laki-laki, memiliki sifat yang kuat, rasional, jantan, dan perkasa. Studi kasus dalam penelitian ini mengambil restoran yang berada di Bandung. Akhir-akhir ini banyak menjamur restoran serta kafe-kafe di Bandung yang mengusung konsep gender dalam penerapan tema sebagai identitas restorannya dan menjadi ciri khas yang membedakannya dengan restoran lainnya. Salah satu contoh restoran yang mengusung konsep gender yaitu restoran Roemah nenek yang berlokasi di jalan Taman Cibeunying selatan dan restoran Nanny's pavillon yang berlokasi di jalan RE. Marthadinata Bandung. Restoran tersebut merupakan restoran yang memperlihatkan identitasnya dengan mengangkat karakter serta sifat keperempuanan pada desain restorannya, sesuai dengan brand yang dihadirkan.

Persoalan tersebut akan menarik diteliti, untuk melihat bagaimana keterkaitan antara gender dengan pembentukan restoran, khususnya di jaman modern ini dan bagaimana gender yang merupakan persoalan sosial dapat menjadi identitas pada fisik sebuah restoran. Oleh karena itu, penelitian ini mencoba mencari kaitan antara identitas, gender dan restoran.

\section{METODE PENELITIAN}

Penelitian ini bersifat kualitatif dengan melakukan pengujian berdasarkan teori yang mempersoalkan aspek-aspek penerapan identitas gender pada elemen interior restoran. Selanjutnya akan digunakan skala penilaian tertentu untuk menguji penelitian yang dilakukan berdasarkan teori dengan menggunakan metode komparatif dengan menilai makna konotatif di balik suatu elemen interior. 
Makna konotasi yang diukur dari sebuah objek dilakukan dengan pendekatan melalui perbedaan semantik atau bisa disebut dengan perbedaan kesan makna yang hadir secara emosional dari masing-masing pengamat. Metode ini dilakukan untuk mencari konsep atau ungkapan yang terkandung di balik objek desain arsitektur dan diukur dalam suatu skala pengamat.

Teori yang digunakan pada penelitian ini adalah Semantik Dalam Arsitektur yang dikaitkan dengan teori Gender, yang akan diuraikan secara singkat dibawah ini.

\section{Semantik Dalam Arsitektur}

Semantik merupakan bidang ilmu yang merupakan bagian dari semiotika, yang mengkaji hubungan antara tanda dan makna. Istilah semiotika berasal dari bahasa Yunani, semeion, yang memiliki arti kurang lebih sama sebagai tanda, yang istilah ini telah lama digunakan oleh para ahli di bidang bahasa atau filsafat. Dalam bidang arsitektur dan interior, semiotika bertujuan untuk memahami suatu bentuk arsitektur dan susunan tata ruang yang mengkomunikasikan suatu arti dari tanda (sign) yang ada. dari jaman renaisans hingga jaman pencerahan, sesungguhnya yang dicari yaitu bentuk pemaknaannya. Y.B.Mangunwijaya (2009) pun menuturkan bahwa penciptaan binatang sekalipun tidak dibuat asal saja secara fisik, namun ada unsur-unsur yang "lebih dari asal berguna", terdapat sesuatu yang lebih daripada soal efisiensi teknis dan fungsional bertahan diri secara fisik belaka, namun ada dimensi budayanya, dan terdapat semacam nurani dalam diri makhluk binatang.

Menurut Barthes (1994), setiap sistem penandaan terdiri dari ekspresi dan isi. Penandaan dapat terjadi ketika ada relasi diantara ekspresi dan isi tersebut. Benda-benda arsitektural mempunyai tanda yang memberikan informasi mengenai makna dan fungsi. Benda-benda arsitektural ini mempunyai makna pertama (denotasi) dan mempunyai makna lain juga (konotasi).

Makna denotasi yaitu signifikansi berdasarkan relasi pertemuan antara tanda dan referen, sehingga makna yang dihasilkan merupakan makna primer sebagai sesuatu yang nyata dan masuk akal. Sedangkan makna konotasi yaitu signifikansi berdasarkan relasi melalui pertemuan antara tanda dan rasa atau emosi pemakai dan juga nilai-nilai budaya. Makna yang dihasilkan merupakan makna sekunder. Makna dalam arsitektur difokuskan pada 
subbidang semantik yang berfokus pada pengetahuan makna dan arti dalam satu elemen atau pembentukan.

\section{Korelasi Antara Teori Gender dan Semantik Dalam Arsitektur/Interior}

Gender berbeda dengan sex, merupakan identitas perempuan dan laki-laki yang dipandang melalui sudut pandang sosial dan budaya, ketidaksamaan yang ada pada mereka tidak hanya dilihat dari fisik saja, namun stereotif terhadap mereka ditentukan oleh pandangan yang dianut pada masyarakat di lingkungan mereka tinggal. (Lips ,1993). Persoalan gender pada kehidupan masyarakat, berlaku bukan hanya pada manusia saja, melainkan persoalan ini juga dapat berlaku pada bangunan arsitektur maupun interior. Dalam arsitektur dan interior, persoalan gender dapat terlihat dari hasil karya objek dari masa ke masa, pada budaya masyarakat yang di bentuk pada masanya, melalui pengkajian ilmu semiotika. Dari jaman Renaisans hingga jaman pencerahan, sesungguhnya yang dicari yaitu bentuk pemaknaannya sendiri. Karena jika dinilai dari sisi fisik saja, tanpa memahami maknanya, tidak akan dapat dimengerti.

Dalam budaya barat, terdapat sejarah arsitektur dalam kaitannya dengan gender, diantaranya yaitu sejarah mengenai beberapa aturan pada pencapaian artistik arsitektur Yunani Kuno terhadap bentuk, penempatan, dan proporsi elemen-elemen berupa nilai-nilai kepantasan tertentu yang dikenal sebagai "aturan klasik" (classical orders). Salah satunya yaitu catatan tertua karya Vitruvius yang menuliskan keberadaan aturan klasik ini. Vitruvius menjelaskan mengenai teknik konstruksi kuil, serta menegaskan pula bahwa kuil-kuil dibangun dan diartikulasikan berdasarkan karakter dewa/dewi yang menghuninya. Pada kolom dorik, aturan yang dipakai merupakan aturan yang paling dasar, dengan karakter yang kuat dan kokoh layaknya tubuh laki-laki. Sedangkan karakter ionik berbeda dengan aturan dorik, yaitu proporsinya lebih ramping yang umumnya diasosiasikan dengan keanggunan dan keindahan tubuh wanita. (Sopandi:2013).

Dalam arsitektur, Kolom dorik ini mewakili karakter maskulin, sedangkan kolom ionik mewakili karakter feminin. Pemaparan mengenai sejarah terhadap aturan terbentuknya kuilkuil pada jaman Yunani Kuno yang dibangun berdasarkan karakter dewa/dewi yang menghuninya, mengungkapkan bahwa aspek-aspek yang berhubungan dengan sifat manusia, dapat diterapkan terhadap suatu benda, atau dalam istilah bahasa disebut personifikasi. 
Seperti halnya penerapan unsur gender dalam arsitektur dunia Barat, pengkajian mengenai identitas gender pada penelitian yang dilakukan pun diidentifikasi dengan cara menganalisis bentuk pada elemen interior restoran yang diperbandingkan dengan sifat-sifat fisik dan karakteristik yang dimiliki oleh perempuan yang sifatnya feminin sesuai dengan pandangan masyarakat umum.

Dalam desain interior terdapat teori estetika yang mempelajari berbagai macam elemen yang terkandung di dalamnya, seperti :

(1) Bentuk

Rupa bentuk geometris terdiri dari lingkaran, segitiga dan bujur sangkar. (Ching, 1996). Bentuk terdiri dari bentuk dua dimensi dan bentuk tiga dimensi. Berikut dijelaskan mengenai bentuk dua dimensi dan bentuk tiga dimensi, yaitu Bentuk dua dimensi, terdiri dari lebar dan panjang, seperti permukaan yang memiliki atribut fisik sebagai berikut:

- Tekstur (kasar, halus, acak, mengkilat, keras, tanah)

- Nilai (terang, sedang, gelap)

- Warna (corak dan titik jenuh)

- Pola

- Ketransparanan, ketembusan cahaya, atau keburaman. (Pile,1988: 48-50)

Media seperti lukisan, gambar, dan hasil cetakan merupakan aspek dengan permukaan dua dimensi. Bentuk Tiga Dimensi, terdiri dari panjang, lebar, serta dengan menambahkan kedalaman atau volume, maka terbentuklah sebuah bentuk tiga dimensi.

(2) Material

Elemen-elemen pada suatu ruang terbentuk dari berbagai jenis material, seperti kayu, batu, kain, cat, dan lain-lain. Setiap material yang diterapkan pada elemen interior akan memberikan sifat sesuai dengan karakter pada benda tersebut. Seperti contohnya pada material lantai tegel dapat menampilkan kesan sejuk, resmi, atau memberi rasa santai pada suatu ruang. Material lantai dari batu memberi kesan padat, permanen, dan awet. Lantai marmer membuat suasana menjadi resmi dan anggun. (Ching ,1996). 


\section{PEMBAHASAN}

\section{Analisis Elemen Interior Restoran}

\section{Roemah Nenek}

Elemen-elemen interior dideskripsikan terlebih dahulu berdasarkan sifat karakter yang muncul pada benda seperti titik, garis, bidang, material, tekstur, dan pola. Berikut penjelasan dari hasil analisis yang telah dilakukan terhadap elemen interior restoran Roemah nenek:

a. Furnitur

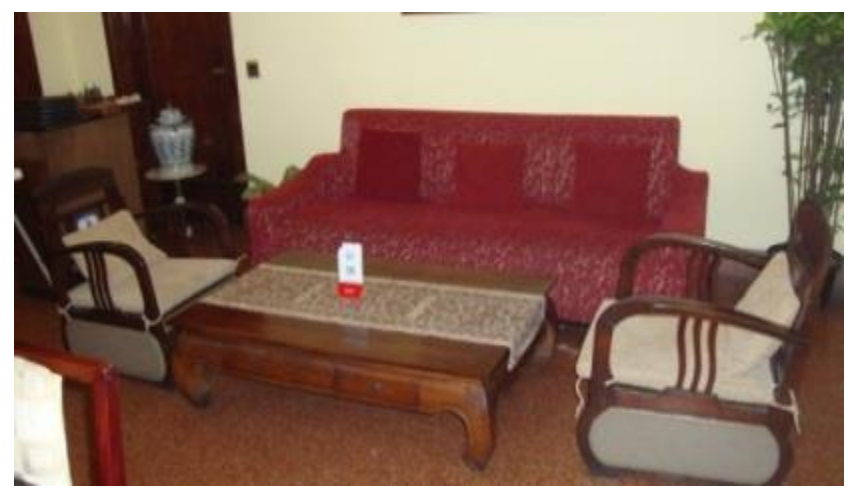

Gambar 1. Furnitur pada

Restoran Roemah Nenek Sumber : Dok. Pribadi (2014)

\section{Analisis elemen terhadap bentuk pada Restoran Roemah Nenek}

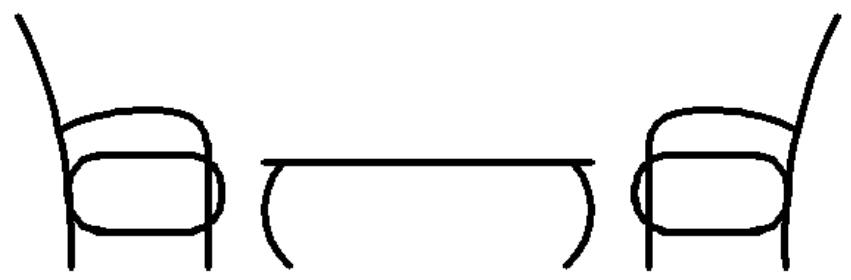

Gambar 2. Susunan pola pada furnitur Restoran Roemah Nenek Sumber : Analisis Pribadi (2014)

Furnitur tersebut tersusun dari garis kursi yang berlekuk, membentuk karakter garis yang luwes, dengan garis meja yang netral karena memadukan antara garis yang sifatnya tegas dan berlekuk, dan juga dibentuk dari garis taplak meja yang tegas. Sedangkan untuk bidang kursi, berbentuk organik, yaitu bidang yang dibatasi oleh garis lengkung yang bersifat halus, serta bidang meja dan taplak meja yang berbentuk bujur sangkar yang bersifat rasional. Sedangkan untuk material, furnitur ini berbahan kain dan busa untuk sofa dan kayu yang sifatnya hangat dan lembut. 


\section{Analisis elemen terhadap pembentuk identitas gender}

Secara keseluruhan, furnitur ini terdiri dari beberapa sifat garis yang luwes, bidang berbentuk bujur sangkar yang bersifat rasional, dan material yang sifatnya hangat dan lembut. Menurut teori gender mengenai stereotip masyarakat, karakter luwes dimiliki oleh perempuan baik pada sifatnya maupun bentuk fisiknya, sehingga dikatakan bersifat feminin dan untuk sifat rasional dimiliki oleh laki-laki sehingga bersifat maskulin. Secara keseluruhan, dikaji dari bentuk, furnitur ini dominan dibentuk oleh karakter yang bersifat feminin. Responden juga menilai bahwa furnitur ini bersifat feminin. Sehingga dapat disimpulkan bahwa pengamatan secara keseluruhan, elemen furnitur ini bersifat feminin.

b. Jendela

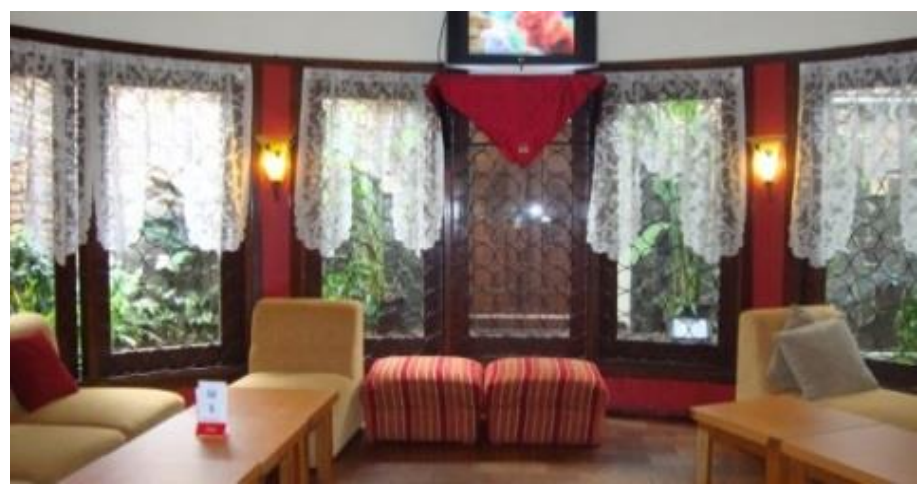

Gambar 3. Jendela pada

Restoran Roemah Nenek

Sumber : Dok. Pribadi (2014)

\section{Analisis terhadap bentuk}

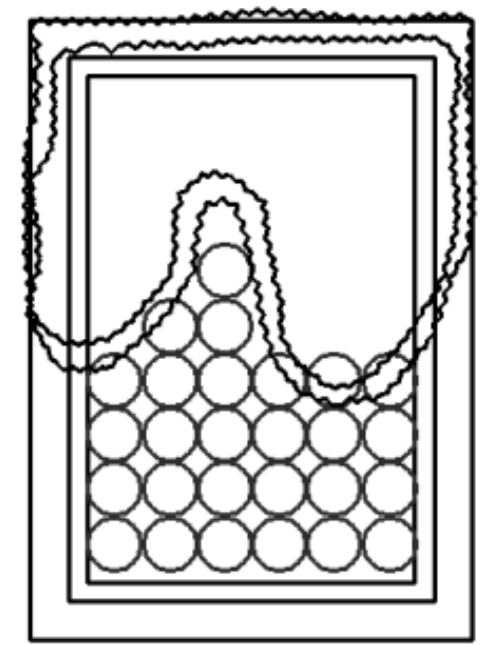

Gambar 4. Susunan pola pada jendela Restoran Roemah Nenek Sumber : Analisis Pribadi (2014) 
Jendela tersebut terbentuk dari garis frame pada kusen yang tegas, dengan garis lingkaran pada tralis, dan juga garis pada tirai yang berlekuk dan terlihat luwes. Sedangkan untuk bidang pada frame jendela ini berbentuk bujur sangkar yang bersifat rasional, dengan material kayu yang sifatnya hangat dan tralis besi yang terkesan dingin serta ringan dengan memiliki tekstur halus. Jendela ini membentuk pola yang dominan berlekuk bersifat lembut dan luwes, berasal dari dominasi pola tirai dan pola tralis.

\section{Analisis elemen terhadap pembentuk identitas gender}

Secara keseluruhan jendela ini terdiri dari beberapa sifat garis yang tegas dan berlekuk atau luwes, bidang berbentuk bujur sangkar yang bersifat rasional juga berbentuk organik (bidang dibatasi oleh lengkung) dan material yang berbahan kayu dengan sifatnya yang hangat, serta besi yang sifatnya dingin dan ringan. Menurut teori gender mengenai stereotip masyarakat, karakter tegas dan rasional dimiliki oleh karakter laki-laki sehingga bersifat maskulin, sedangkan karakter luwes dan ringan baik dari fisik maupun sifat dimiliki oleh perempuan, begitu pula dengan sifat yang terkesan penuh dengan kehangatan (kasih sayang) dominan dimiliki oleh perempuan sehingga dinilai feminin. Secara keseluruhan, dikaji dari bentuk, jendela ini dominan dibentuk oleh karakter yang bersifat feminin. Dan responden pun menilai bahwa jendela ini bersifat feminin. Sehingga dapat disimpulkan bahwa pengamatan secara keseluruhan, elemen jendela ini bersifat feminin.

\section{c. Elemen dekorasi}

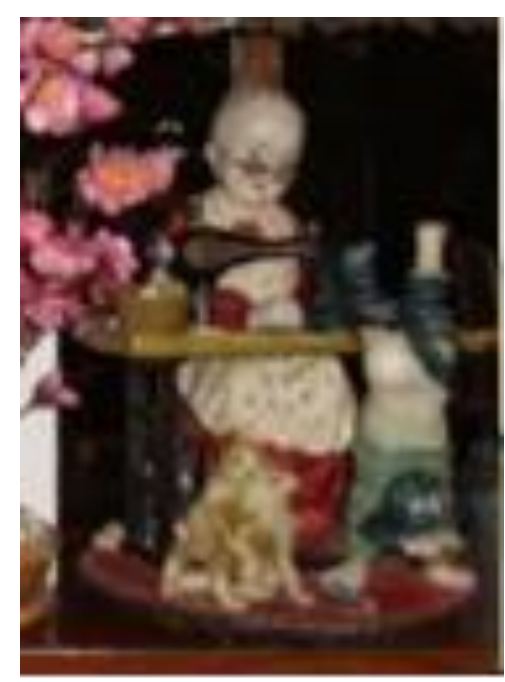




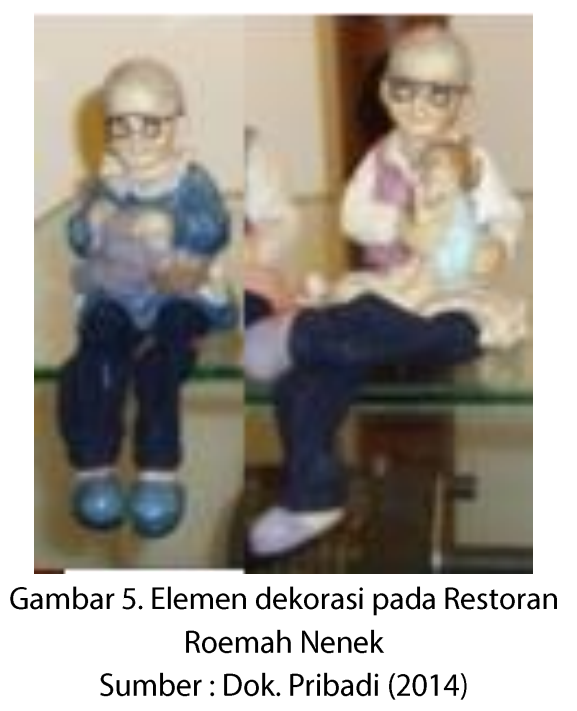

Berdasarkan teori gender, kegiatan sehari-hari seperti menjahit, merajut, dan mengurus cucu merupakan kegiatan yang pada stereotip masyarakat merupakan aktifitas yang identik dengan kegiatan perempuan. Begitu pula responden menyatakan bahwa aktifitas tersebut merupakan pekerjaan rumah tangga yang identik dengan kaum perempuan. Sehingga dapat disimpulkan bahwa elemen dekorasi tersebut bersifat feminin.

d. Hiasan dinding (piring keramik)

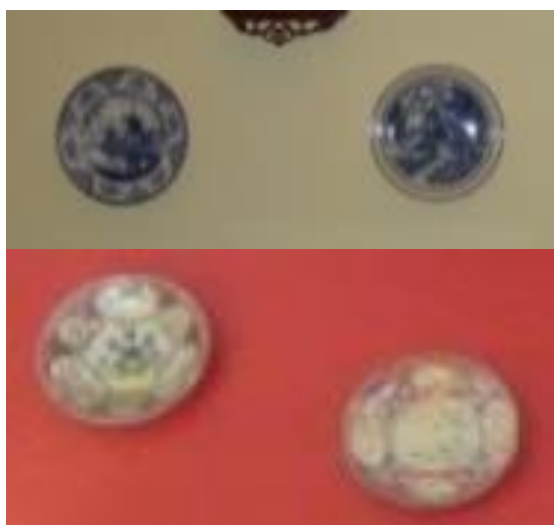

Gambar 6. Hiasan dinding pada Restoran Roemah Nenek Sumber : Dok. Pribadi (2014)

Piring-piring keramik yang dipajang sebagai hiasan dinding ini identik dengan sifat feminin, bentuknya yang melingkar bersifat lembut dan luwes serta permukaannya yang halus juga menambah sifat kefeminiman benda tersebut. Selain itu, pada stereotip masyarakat pun menilai bahwa piring keramik identik dengan peralatan rumah tangga yang bersifat keperempuanan. Sehingga dapat disimpulkan bahwa piring-piring keramik tersebut bersifat feminin. 
Pemaparan diatas mengungkapkan bahwa elemen yang terdapat pada interior restoran Roemah Nenek dominan dibentuk dan mengarah kepada sifat dan karakter perempuan. Terdapat relasi antara tema restoran mengenai gender yang bertitik tolak pada perempuan terhadap elemen interior restoran. Hal itu dapat terlihat dari sifat yang terbentuk dari bentuk elemen-elemen interior. Selain itu, karakter yang menunjukan kegiatan berumah tangga identik sekali dengan brand yang di usung oleh restoran Roemah Nenek ini.

\section{Analisis Elemen Interior \\ Restoran Nanny's Pavillon}

Berikut penjelasan dari hasil analisis yang telah dilakukan terhadap elemen interior restoran Roemah nenek:

a. Dinding

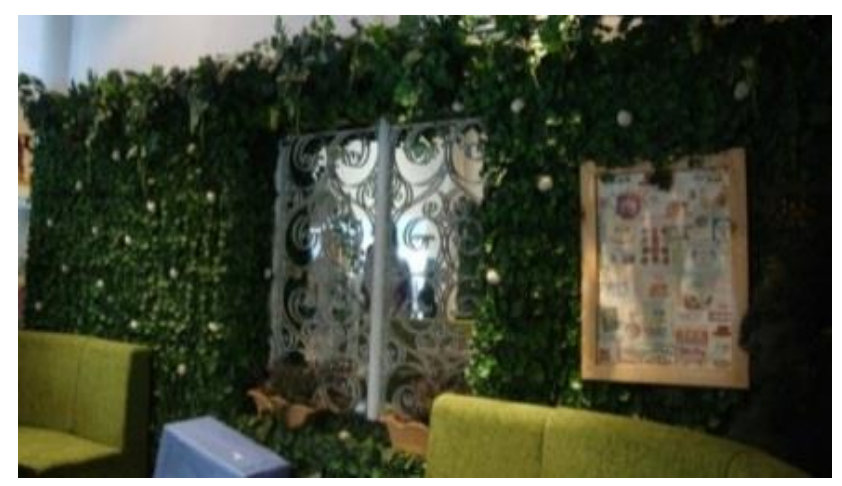

Gambar 7. Dinding pada Restoran Nanny's Pavillon Sumber : Dok. Pribadi (2014)

Analisis terhadap bentuk

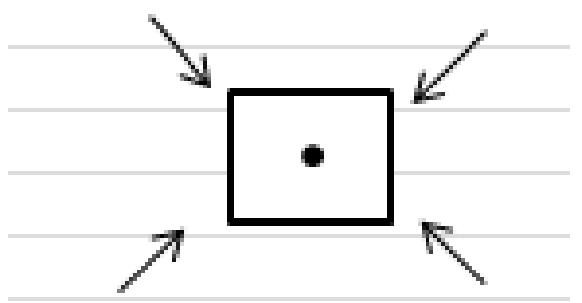

Berkoloni \& telindungi

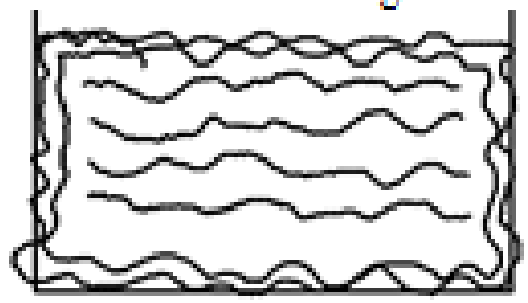

Gambar 8. Susunan titik,garis dan pola pada dinding Restoran Nanny's Pavillon Sumber : Analisis Pribadi (2014) 
Dinding tersebut dilapisi oleh elemen dekorasi tanaman rambat plastik dengan bentuk sebagaimana tanaman aslinya. Dinding ini tersusun dari titik-titik yang berkoloni dan terlindungi. Sedangkan untuk garis, membentuk garis-garis yang berlekuk luwes sehingga membentuk bidang dengan pola yang bersifat organik, seakan berkesan tumbuh. Bahan dari elemen dekorasi tanaman pada dinding ini yaitu plastik, yang bersifat ringan.

\section{Analisis elemen terhadap pembentuk identitas gender}

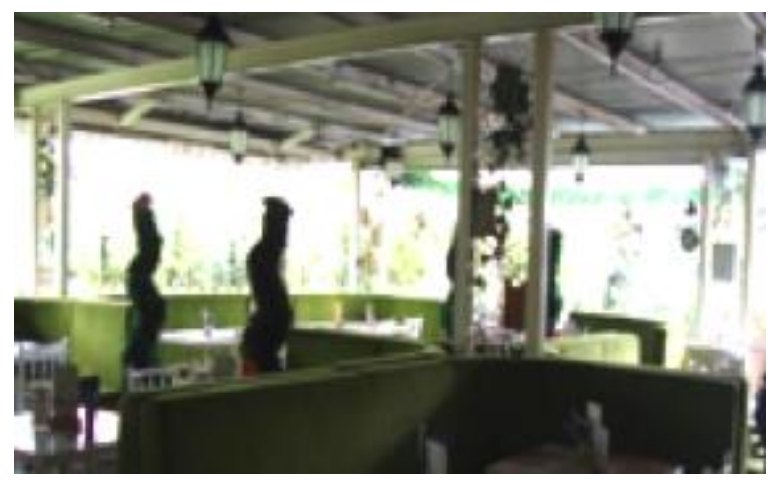

Secara keseluruhan dinding dengan tanaman rambat ini tersusun atas titik-titik yang berkoloni dan terlindungi, dengan garis yang luwes dengan bidang yang bersifat organik, dan material plastik yang sifatnya ringan. Jika dikorelasikan dengan teori gender mengenai stereotip masyarakat terhadap sifat-sifat seperti berkoloni, terlindungi, dan luwes merupakan sifat yang identik dengan perempuan yaitu feminin. Selain itu, bunga-bunga kecil berwarna putih yang tersebar pada dedaunan pun identik dengan perempuan. Jadi, secara keseluruhan dikaji dari bentuk, dinding ini dominan dibentuk oleh karakter yang bersifat feminin. Dan responden pun menilai bahwa dinding ini bersifat feminin. Sehingga dapat disimpulkan bahwa pengamatan secara keseluruhan, elemen dinding ini bersifat feminin. 
Serat Rupa Journal of Design, January 2016, Vol.1, No.1:50-63

Aan Setiawati - Elemen Pembentuk Identitas Gender pada Restoran Bertema Perempuan di Kota Bandung

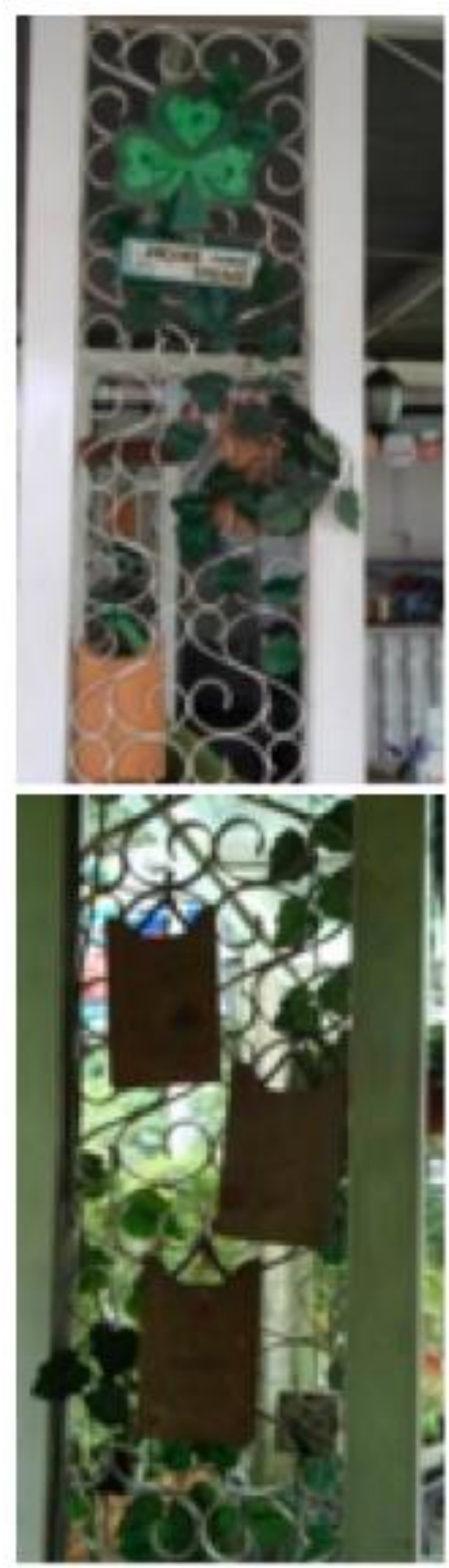

Gambar 9. Kolom pada Restoran Nanny's Pavillon Sumber : Dok. Pribadi (2014) 


\section{Analisis Terhadap Bentuk}

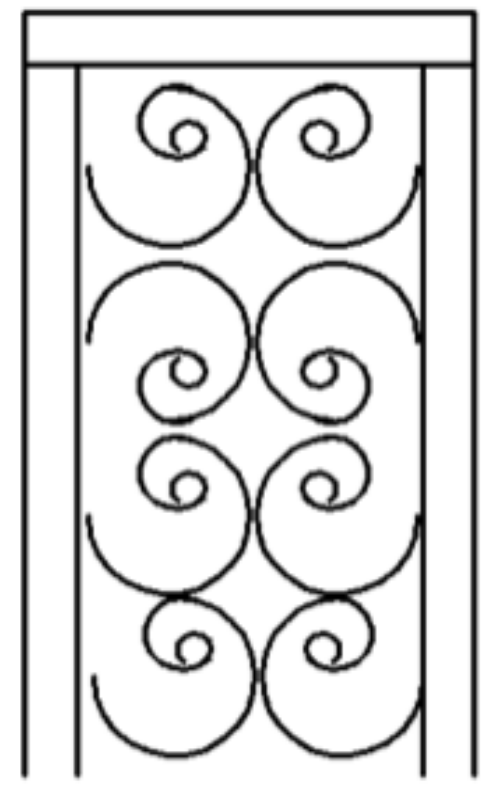

Gambar 10. Susunan garis dan pola pada kolom Restoran Nanny's Pavillon

Sumber : Analisis Pribadi (2014)

Deretan kolom tersebut terbentuk dari garis yang tegas, ditambah dengan lengkungan pada tralis sehingga terlihat luwes. Sedangkan untuk bidang yang menjadi frame, berbentuk persegi panjang yang bersifat rasional, dengan material kayu yang sifatnya hangat dan tralis besi yang terkesan dingin serta ringan. Secara dominan, kolom ini terlihat luwes, yang berasal dari dominasi pola lengkung pada tralis.

\section{Analisis elemen terhadap pembentuk identitas gender}

Secara keseluruhan kolom ini terdiri dari beberapa sifat garis yang tegas dan berlekuk atau luwes, bidang berbentuk persegi panjang yang bersifat rasional dan material yang berbahan kayu dengan sifatnya yang hangat, serta besi yang sifatnya dingin dan ringan. Menurut teori gender mengenai stereotip masyarakat, karakter tegas dan rasional dimiliki oleh karakter laki-laki sehingga bersifat maskulin, sedangkan karakter luwes dan ringan baik dari fisik maupun sifat dimiliki oleh perempuan, begitu pula dengan sifat yang terkesan penuh dengan kehangatan (kasih sayang) dominan dimiliki oleh perempuan sehingga dinilai feminin.

Secara keseluruhan, dikaji dari bentuk, kolom ini dominan dibentuk oleh karakter yang bersifat feminin. Dan responden pun menilai bahwa kolom ini bersifat feminin. Sehingga dapat disimpulkan bahwa pengamatan secara keseluruhan, elemen kolom ini bersifat feminin. 
b. Elemen dekorasi

(vas bunga "boots')
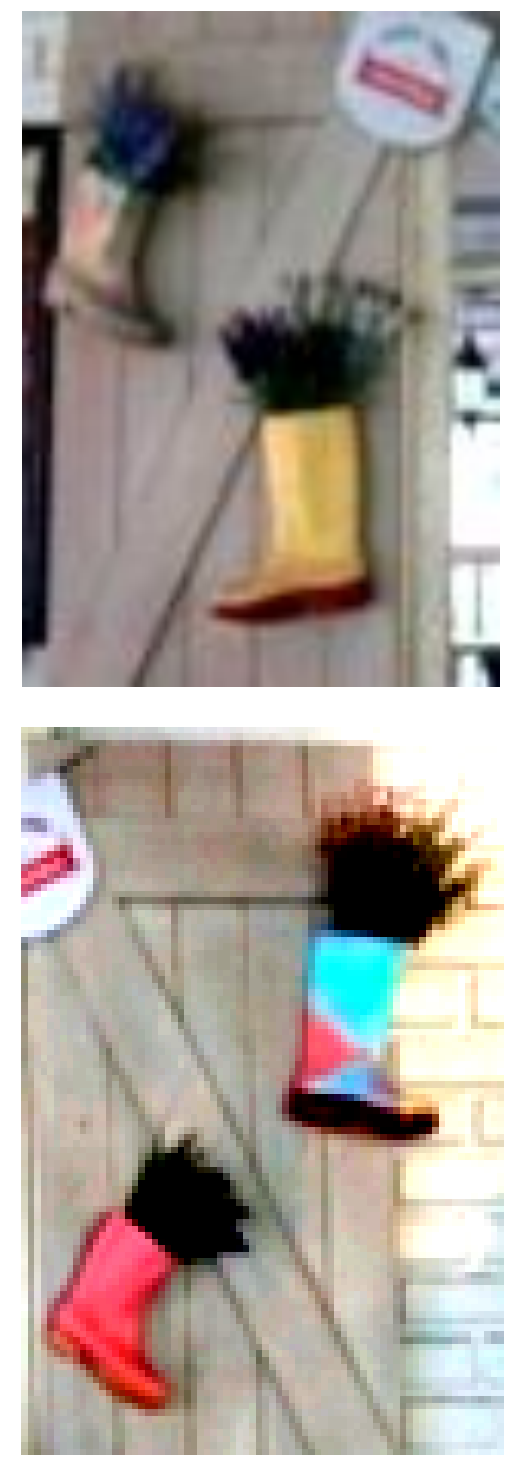

Gambar 11. Elemen dekorasi pada

Restoran Nanny's Pavillon

Sumber : Dok. Pribadi (2014)

\section{Analisis elemen terhadap pembentuk identitas gender}

Elemen dekorasi ini yaitu vas bunga dari sepatu boots, jika dilihat dari bentuk dan fungsi aslinya sebagai sepatu, benda ini lebih berkarkter maskulin. Akan tetapi ketika sepatu boots tersebut dijadikan barang dengan fungsi lain, yaitu vas bunga dengan di beri warna-warna lembut yang sifatnya feminin, hal ini menjadi beruba penilaian terhadap benda tersebut. Responden pun berpendapat bahwa vas bunga "sepatu boots" ini memiliki sifat yang feminin. Sehingga dapat disimpulkan bahwa dari pengamatan secara keseluruhan, elemen dekorasi vas bunga ini bersifat feminin. 
C. Furnitur

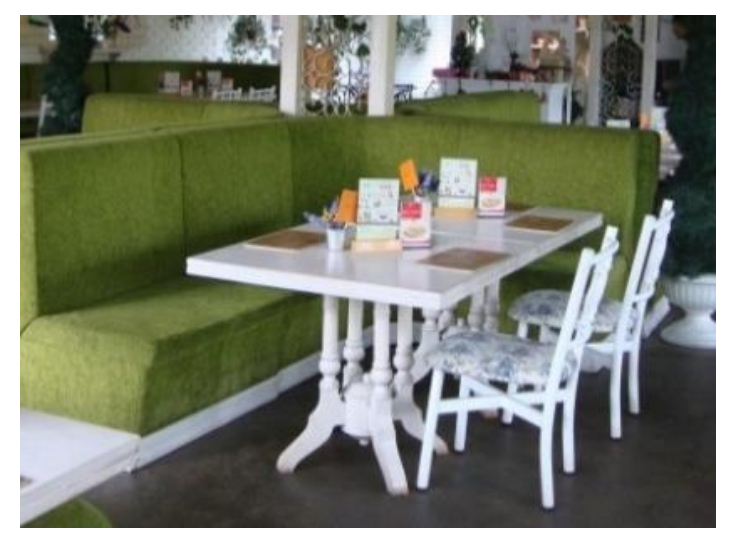

Gambar 12. Furnitur pada

Restoran Nanny's Pavillon

Sumber : Dok. Pribadi (2014)

\section{Analisis terhadap bentuk}

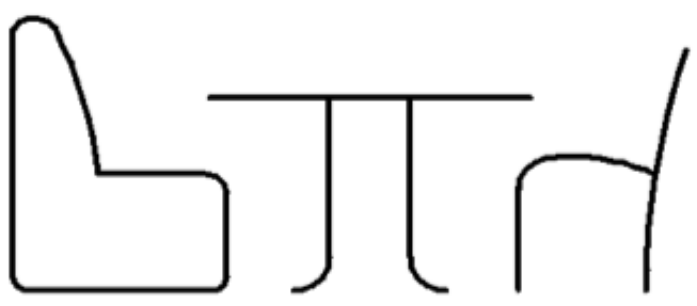

Gambar 13. Susunan garis dan pola pada furnitur Restoran Nanny's Pavillon Sumber : Analisis Pribadi (2014)

Furnitur tersebut terbentuk dari garis kursi yang berlekuk, membentuk karakter garis yang luwes, dengan bidang kursi yang organik, yakni bidang dibatasi oleh garis lengkung. Sedangkan bidang pada meja berbentuk persegi bersifat rasional. Untuk material, furnitur pada kursi sofa dan meja berbahan kain dan busa yang lembut, serta dari bahan kayu yang sifat karakternya hangat dan lunak.

\section{Analisis elemen terhadap pembentuk identitas gender}

Secara keseluruhan, furnitur ini terdiri dari beberapa sifat garis yang luwes, bidang berbentuk bujur sangkar yang bersifat rasional, dan material yang sifatnya hangat dan lembut. Menurut teori gender mengenai stereotip masyarakat, karakter luwes dimiliki oleh perempuan baik pada sifatnya maupun bentuk fisiknya, sehingga dikatakan bersifat feminin dan untuk sifat rasional dimiliki oleh laki-laki sehingga bersifat maskulin. Secara keseluruhan, dikaji dari bentuk, furnitur ini dominan dibentuk oleh karakter yang bersifat 
feminin. Dan responden pun menilai bahwa furnitur ini bersifat feminin. Sehingga dapat disimpulkan bahwa pengamatan secara keseluruhan, elemen furnitur ini bersifat feminin.

Pemaparan diatas mengungkapkan bahwa elemen yang terdapat pada interior restoran Nanny's Pavillon dominan dibentuk dan mengarah kepada sifat dan karakter perempuan. Terdapat relasi antara tema restoran mengenai gender yang bertitik tolak pada perempuan terhadap elemen interior restoran. Hal itu dapat terlihat dari sifat yang terbentuk dari bentuk dan warna elemen-elemen interior.

\section{PENUTUP}

Penerapan unsur elemen interior pada restoran memunculkan makna bahwa perempuan masih berkaitan erat dan "terkurung" dalam aktivitas domestik di dalam suatu bangunan yang dinamakan rumah. Sebuah bangunan tersusun atas elemen-elemen yang membentuknya, dan dari susunan tersebut terbentuklah sebuah makna. Seperti halnya sebuah kalimat yang terbentuk dari beberapa susunan kata, membentuk suatu makna yang tersirat dalam kalimat tersebut.

Dalam konteks makna bangunan ini terdapat 3 hal yang terlibat, diantaranya pembuat bangunan, pesan yang termuat dalam bangunan, dan pembaca bangunan melalui kode yang ada. Makna yang tersirat dari susunan elemen interior pada restoran memiliki arti sebagai berikut :

Gagasan membuat bangunan restoran ini dimiliki oleh masyarakat modern dimana tidak lagi menerapkan unsur gender pada bangunannya yang berpatokan pada kepercayaan rohroh nenek moyang seperti pada rumah tradisional, yang mengkotak-kotakan area khusus bagi laki-laki ataupun perempuan. Akan tetapi penerapan unsur gender pada bangunan didasarkan pada kesan stereotif masyarakat secara umum yang secara turun temurun berkembang di masyarakat. Walaupun pada masyarakat modern ini aturan penerapan unsur gender tidak secara gamblang diutarakan dan dibentuk dalam sebuah tata aturan kemasyarakatan, khususnya dalam sebuah bangunan, namun masih tersirat unsur di dalamnya yang apabila dikaji secara detail, persoalan gender tersebut masih nampak. Hal tersebut terlihat ketika dilakukan pengkajian terhadap sifat-sifat yang muncul pada karakter elemen interior yang berkaitan erat dengan sifat dan peran perempuan di dalam kehidupan berumah tangga. 
Bangunan restoran ini mempunyai image perempuan yang diperkuat dengan dominasi elemen interior yang mempersepsikan sifat dan peran perempuan di dalamnya, hal ini berhubungan dengan gender. Unsur gender yang tersirat dapat terlihat dari dominasi sifat pada elemen interior yang memiliki korelasi makna dengan sifat dan peran perempuan dalam kehidupan bermasyarakat. Seperti pada dominasi elemen interior yang merepresentasikan makna gender diterapkan pada unsur-unsur pembentuk ruang dan elemen dekorasi pada ruangan. Elemen interior yang dihadirkan pada restoran memiliki ciriciri yang memiliki hubungan dengan ciri sifat serta peran dan fungsi perempuan dalam kehidupan bermasyarakat, yang berkaitan dengan persoalan gender.

Ekspresi pada penerapan elemen interior pada bangunan restoran ini memiliki nilai tertentu yang dikenal umum di masyarakat, yaitu keterkaitan antara perempuan dengan kegiatan yang berlangsung di dalam kegiatan berumah tangga, dan keterkaitan antara sifat-sifat perempuan dengan sifat-sifat elemen interior.

Membahas mengenai persoalan gender, secara umum perempuan seringkali ditempatkan pada posisi objek daripada laki-laki yang menjadi subjek. Sehingga untuk penelitian selanjutnya, persoalan mengenai gender perlu dikaji lebih mendalam, terutama terhadap dampak yang muncul dari isyu gender ini pada desain arsitektur atau interior.

\section{DAFTAR PUSTAKA}

Barthes, Roland. (1994). Elements of semiology. New York: Hill and Wang.

Ching. Francis D.K. (1996). Interior Design Illustrated. dalam versi bahasa Indonesia diterjemahkan oleh Ir. Paul Hanoto A. Jakarta : Erlangga.

Lips, Hilary M. (1993). Sex and Gender: An Introduction. London: Myfield Publishing Company. Mangunwijaya, Y.B. Wastu Citra. (2009). Jakarta: PT. Gramedia Pustaka Utama.

Pile, Jhon F. (1988). Interior Design. New York: Harry N. Abrams, Incorporated.

Sopandi, Setiadi. (2013) . Sejarah Arsitektur Sebuah Pengantar. Jakarta: PT. Gramedia Pustaka Utama. 